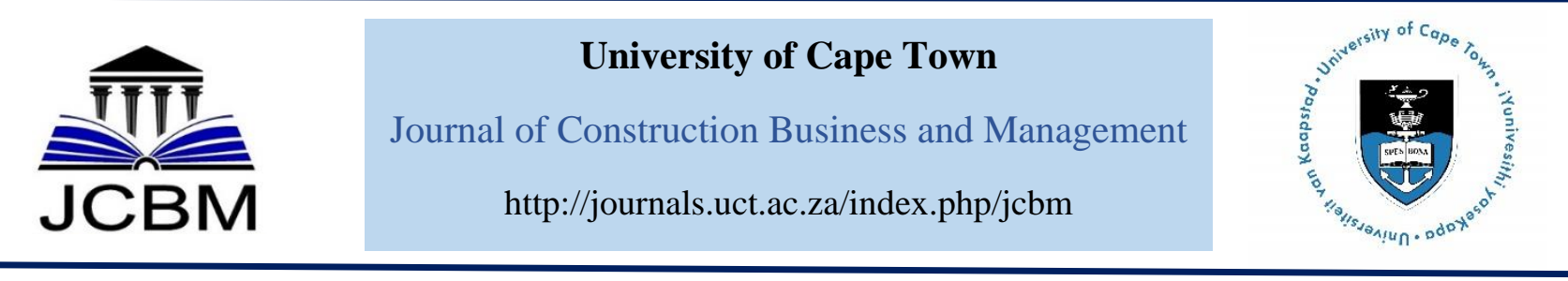

\title{
Duties and Required Competencies of a Management Contractor
}

\author{
C. Ayegba ${ }^{1}$ \\ School of Construction Economics and Management, University of the Witwatersrand, South Africa ${ }^{1}$
}

Received 15 November 2016; received in revised form 26 March 2017, 3 June 2017; accepted 7 July 2017

\begin{abstract}
One of the responses to the critical failings of separation of design and construction processes of traditional procurement system is the development of management contracting (MC) procurement system. Several studies have indicated MC procurement system to be most suitable for large and complex projects, when on-time project delivery is required, and when flexibility during construction is desired. Owing to the involvement of the Management contractor at both design and construction stage of projects, the management contractors play more significant role in the benefits that MC system has shown to deliver. This study aims to investigate the duties performed by the management contractor and the required competencies for a management contractor, to provide knowledge and understanding on important considerations for the selection of a management contractor. Empirical data was collected using documentary analysis of three management contracts tender documents and a semi-structured interview with a key role player of two of the management contracts in South Africa. Findings revealed the duties performed by management contractors to be multitasking, covering both the preconstruction and construction stage of building projects. Also, owing to the increased responsibilities of management contractors, the competencies required to perform as a management contractor are distinguishable when compared to competencies needed of contractors to perform in other procurement systems. The knowledge and understanding of the duties and required competencies to perform as management contractors provided in this study will help construction clients and the construction industry in the selection process, performance management and evaluation of management contractors.
\end{abstract}

Keywords: Construction procurement, Management and relationship formation duties, Management contracting procurement system, Management contractor.

\section{Introduction}

There has been increasing advocacy in favour of a procurement system that supports the requirements for integration in construction in recent years (Smith and Offordile, 2008; Watermayer, 2012). The increased advocacy is linked to the influence of the Latham 1994 "constructing the team" and Egan 1998 "rethinking construction" reports, which suggest the separation of design and construction processes as the fundamental weakness of the construction industry. The procurement systems that absorb contractor's involvement at both the design and construction stages as described by Murdoch and Hughes (2008) are MC procurement system, and design and build system. Nevertheless, unlike in design and build, management contractors in MC do not undertake the actual design and construction themselves. Designers usually do have a separate contract with clients, while the real construction works are sub-contracted to work contractors by the management contractor (ibid). The Chartered Institute of Building (CIOB, 2010) survey report on procurement in the construction industry indicated that as construction projects increase in complexity and value, the management contracting system tends to be the preferred choice of construction procurement adopted by construction clients over the other procurement systems. As well, in a Survey on construction industry indicators by the Construction Industry Development Board (cidb, 2014) management contracting system was indicated to be the second most used procurement system by national and provincial departments after the traditional system which is also referred to as general contracting procurement system.

In a study evaluating management contracting and investigating the significant difference in clients perspective of performance criteria between management

\footnotetext{
${ }^{1}$ Corresponding Author. Tel: +27838577321

Email address: 1174370@students.wits.ac.za
} 
and traditional procurement systems by Sidwell (1983) and Naoum (1994) respectively; the benefits in management contracting system were attributed to the improved integration of project team members, flexibility of the system, breaking down of work into packages with total competition of work packages, improved collaboration, risk sharing, early contractor's involvement and more relational relationship enhanced by the management contractor.

The distinguishing feature of the management contracting system from the traditional method is the introduction of a management contractor at the design stage of the project. According to Murdoch and Hughes (2008), the introduction of the management contractor allows for the contribution of the management contractor's experience and expertise in the design and construction management of projects. Therefore, the reported benefits of the system can be as a result of the roles and duties performed by the management contractor. While available research on MC emphasises more on the advantages and suitability of using the system (see Naoum, 1994; Naoum and Langford, 1987; Sidwell, 1983; Ward et al., 1991). Limited attention has been given to investigating the performed duties and the required competencies to perform as a management contractor that has resulted in the reported benefits MC has shown to deliver.

The aim of this research, therefore, is to investigate the duties performed by management contractors and the required competencies for management contractors to carry out their functions efficiently.

\section{Literature Review}

\subsection{Management contracting procurement system}

The established procurement systems in the construction industry are management contracting, traditional procurement (also known as general contracting or design-bid-build system), design and build and construction management procurement system. Others, as suggested by Macaulay and Ramsey (2002) are hybrid procurement systems based on a combination of one or more of the procurement systems mentioned above.

Each of these construction procurement systems differs in the way they allocate responsibility and liability to contractors for design, construction and management of construction works. For example, from the details in the following textbooks by Hughes et al (2006: 7-12), Masterman (2003: 23-116) and Murdoch and Hughes (2008: 27-79): in the traditional system of procurement, the contractor is only involved at the construction stage of projects, where they undertake construction works only, without any responsibilities or inputs at pre-construction and project design stages; in the design and build system, the contractors are responsible for both the design (based on clients brief) and the construction works of the project; while in a management contracting system, the contractors are responsible for the performance of the whole contracts, including defining packages of work and management of construction works which are subcontracted to work contractors.

Management contracting evolved from the United Kingdom (UK) (Sidwell, 1983). According to Murdoch and Hughes (2008), the system has been in use for a considerable period even though it was only in 1987 that a standard form of contract was developed for it. The horizon factory in Nottingham for John payer limited designed by Arup and Associates and built by Bovis limited, and the British Library in London where among the earliest projects built using this system (Murdoch and Hughes, 2008; Sidwell, 1983).

The international standard organisation (ISO 10845-1 2010) describes management contracting system as a procurement system in which the contractor provides consultation during the design stage and is responsible for planning and managing all post contract activities and for the performance of the whole contract. In contrast to the practice in a construction management system or a traditional procurement system in which contractor also go into direct contract with the client, only the management contractor goes into construction work contract for the entire building project with the client, and takes responsibility for the administrative and operational works of the contract in a management contracting system (Al-Harthi et al., 2014b; Murdoch and Hughes, 2008; Naoum, 1994; Sidwell, 1983; Ward et al., 1991). Therefore, the system is indicated to consist of $100 \%$ subcontracting, since every item of the work is subcontracted to work contractors. However, in the guidance on procurement and contract strategies provided by the Institute of Civil Engineers (ICE, 2005: 7) management contractors may also participate in some actual construction works.

In the Joint Contract Tribunal guidance note as highlighted by Murdoch and Hughes (2008: 61) the suitable circumstances in which management contracting can be used as a procurement option includes: when design is to be carried out by an independent architect and design team, when there is need for early completion since work can begin while complete design is still being undertaken and when project requirements are significant. Others are when there is need to change the client's requirements during the construction stage and when the maximum possible competition concerning price is required. Also, the delivery management guidelines Practice Guide 2 on construction procurement strategy of the Construction Industry Development Board (cidb, 2011) suggests that a management contract is appropriate in the following project environment: where there is limited capability or capacity to advance the work beyond a strategic brief, when the contractor needs to work alongside the design team to develop the programme for design, when the employer has limited resources to manage and procure some construction work contracts, and when single point accountability is desired for the delivery of a series of projects. However, Naoum and Langford (1987) argued that many contracting organisations enter management contracting without the right personnel and do not understand the change in status as they just regard themselves as administrative middlemen between the sub-contractors and the client, and thus do not inject any creative ideas into the project procurement process.

2.2 Difference between management contracting and the traditional procurement system 
On review of organization structure and contractual relationships of management contracting and the traditional system of procurement as provided by (Alharthi et al., 2014; Murdoch and Hughes, 2008; Naoum, 1994; Naoum and Langford, 1987; RICS, 2012;
Sidwell, 1983; Ward et al., 1991), Figure 1 and Figure 2 were developed to illustrate the contractual relationship and organization structure in expressing the differences between management contracting and traditional procurement system.

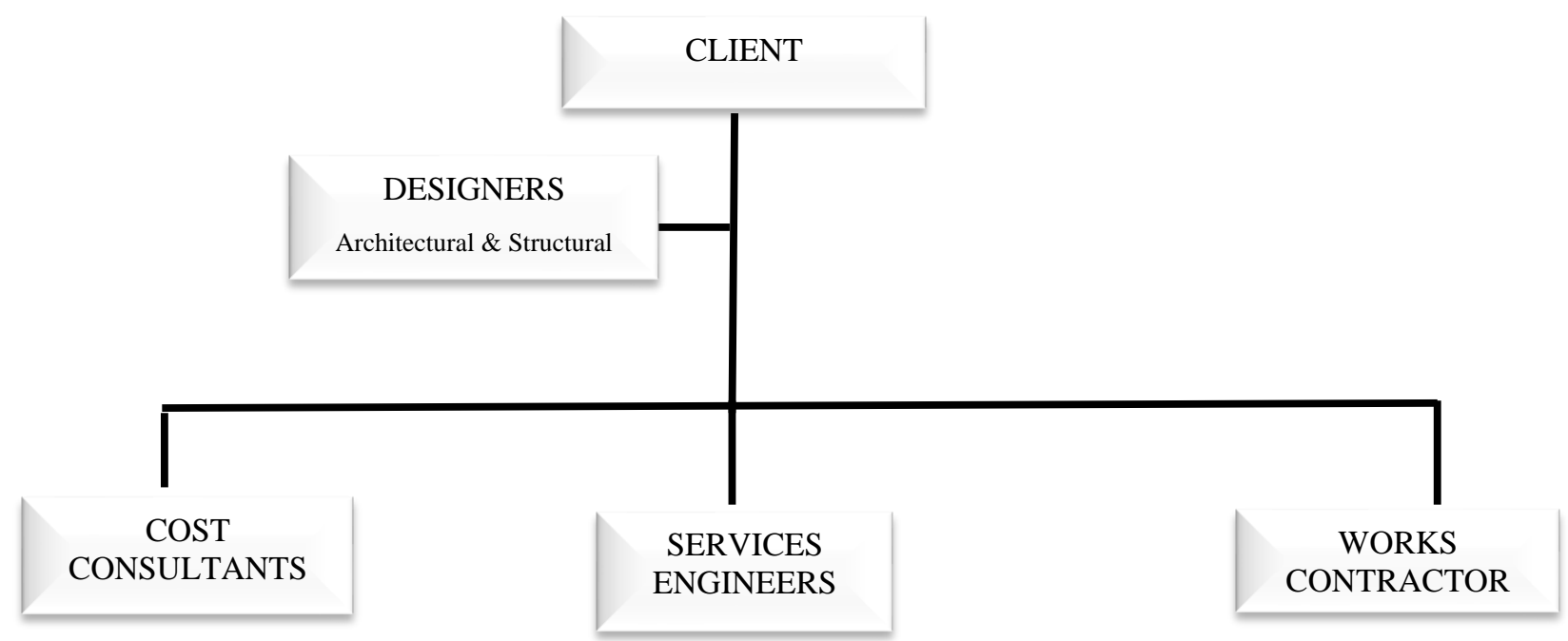

Figure 1. Traditional Procurement System

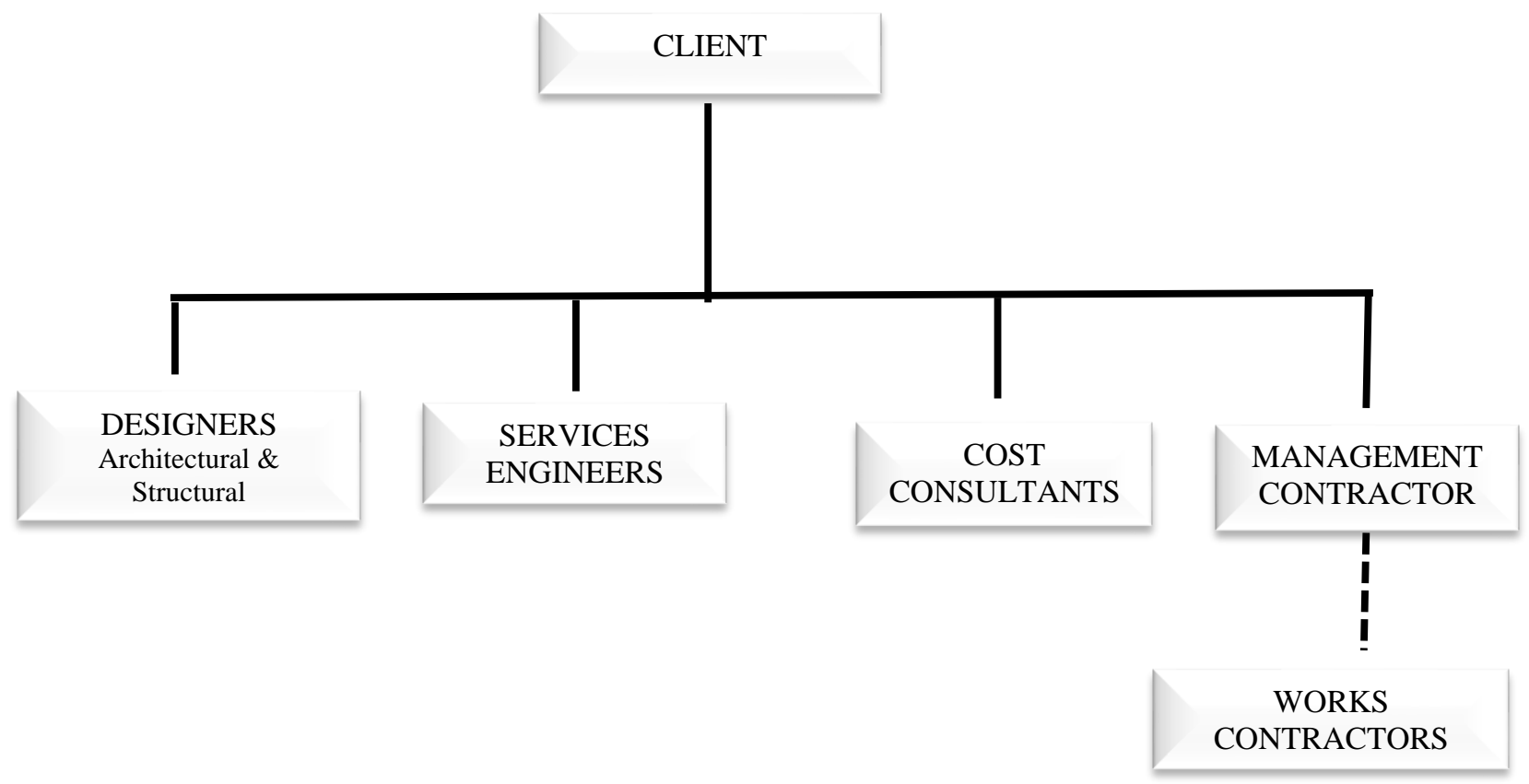

Figure 2. Management Contracting Procurement System

In the traditional procurement system shown in Figure 1, work contractors have a direct contractual relationship with the client. This will result in a more active role by the customer in contrast to what is the practice in management contracting, where only the management contractor has a contractual relationship with the client (see Figure 2). The management contractor then appoints and manages the work contractors who are contractually accountable to the management contractor. This enables clients to take more detached roles in the project procurement process as suggested by (Naoum and Langford, 1987). Figure 2 also shows that the management contractor is elevated to the same level as the project consultants, enabling the management contractor to offer services both at the design stage and as well as the construction stage. With this arrangement, the consultants will be having access to the expertise and experience of the management contractor at the pre-construction stage, which will result in improved services from the consultants. According to Murdoch and Hughes (2008) the opportunity provided for contractors to have the same status with the consultants is the primary reason why contractors favored a management contracting system to the traditional method, where contractors are directly placed under the scrutiny of consultants or the project's principal agent, which usually are architects depending on the type of project. 
Also, in contrast to the practice in traditional procurement system in which designs are typically completed before construction commences, in management contracting, the management contractor, being a member of the design team and a member of the construction team is engaged early at the pre-construction stage of the project. Thereby facilitating the overlap of designs and construction processes. This practice is attributed to the flexibility and early project completion feature in management contracting system (Naoum, 1994; Sidwell, 1983 and Ward et al., 1991).

Furthermore, in management contracting system, subcontracting is a major distinguishing feature. The management contractor does no construction work but rather subcontract all the works, which are usually broken down into work packages to the work contractors as submitted by (Alharthi et al., 2014 and Murdoch and Hughes, 2008). Contrary to the traditional system, where the work contractor is responsible for the actual construction of work and may use subcontractors as well. Also, contractors in a traditional system are often paid a lump sum for the contract, but in management contracting, management contractors usually go into a fee contract and are paid a prime cost for all works done plus a fee. Although Murdoch and Hughes (2008) argued that certain direct works such as site staffing, provision of labour and materials and sundry cost services provided by the management contractor should be dealt with on a lump sum basis instead of cost reimbursement.

From the preceding, the differences in management contracting appear to be responsible for the added advantages attributed to the system over the traditional procurement system. Thereby, making management contracting a more suitable procurement route particularly for large and complex projects, and when early completion and flexibility during construction is desired.

\subsection{Duties of a Management Contractor}

As a result of the increase in responsibilities of the management contractor, in being a consultant as well as a contractor, and in providing services at the preconstruction stage and the construction stage, the benefits in management contracting could be attributed to the duties performed by the management contractor. Owing to the different roles and responsibilities of the management contractor, the tasks carried out by the management contractor can be argued to be distinct from that of a general contractor in a traditional system. This calls for clarification of the duties of the management contractor and to categorise them accordingly in the different phases of a construction project.

In a case study involving 39 management contracts and 30 traditional contracts in the UK, in investigating whether the means of procurement influenced project performance, Naoum (1994) reported that management contractor's liability and responsibility is not apparent, and there is not enough evidence to support how management contracting reduces overall building cost and quality of projects. This report may be an indication of a gap in knowledge on the duties performed by management contractors. However, Murdoch and Hughes (2008: 64) asserted that due to the functions carried out by the management contractor, the roles of a contract administrator and a quantity surveyor might not be defined in a management contract.

Essentially the duties performed by the management contractor are divided into pre-construction period duties and construction period duties (Murdoch and Hughes, 2008: 64). At the pre-construction stage, the management contractor performs duties such as professional team integration, advising on the breakdown of work packages and assisting with negotiations. While responsibilities such as programming and planning, monitoring off-site preparation work, instituting effective cost control techniques, labour relations and site management are performed by the management contractor at the construction stage, in addition to providing site facilities and services. Sidwell (1983) submits that the two most important duties of the management contractor are in subcontractors control and design team integration. Similarly, Ward et al. (1991) have reported coordination of work responsibilities and liabilities and control functions as the duties performed by a management contractor. These identified management contractor duties appear comparable to management duties as defined by Mintzberg (1973: 92) that includes: the interpersonal role of figurehead, leader and liaison; the informational role of monitor, disseminator and spokesman; and the decisional role of entrepreneur, disturbance handler, resource allocator and negotiator. An earlier view of managerial duties was described by Henry Fayol in 1916 (Fayol, 1954) to include Planning, organising, controlling, commanding and coordinating.

\subsection{Required Competencies of a Management Contractor}

Competency has been described as the knowledge, skills, and behaviours required to perform well and to keep up with the culture of an industry (Delo et al., 2010). Mirabile (1997) earlier describes competency as the "knowledge, skill, ability or characteristic associated with high performance on a job, such as problem-solving, analytical thinking, or leadership." For a management contractor to perform required duties in management contracting effectively, it can be argued that the management contractor needs certain competencies.

Several studies have sought to identify required skills and their relationship to positions and performance in different jobs. For example, in a report evaluating management contracts in the UK, Sidwell (1983) identified builder's management, construction, estimating, buying and planning as skills made available to design teams by management contractors which brings the benefits of speed, economy, and construction method. Meredith and Mantel Jr (2011: 142) categorise project management required competencies into six key skill areas, to include: communication, organisation, team building, leadership, coping and technological skills. According to Delo et al. (2010), recurring themes of competencies include behaviours such as self-control, resilience, communication, self-assurance, and those related to team leadership. Dainty et al. (2005) suggest that Construction project managers must combine technical knowledge and expertise with behaviours that engender effective multiorganizational teamwork and communication to achieve successful outcomes. They 
further identified the competencies for project management performance to include the following: achievement orientation, initiative, information seeking, focus on client's needs, impact and influence, directedness, teamwork and cooperation. Others are team leadership, analytical thinking, conceptual thinking, selfcontrol, and flexibility; with self-control and team leadership being indicated as the core competencies. Owing to the increased responsibility management contractors are expected to perform, undoubtedly the knowledge of their required competencies may provide clients with information for appropriately selecting a management contractor that is capable of achieving the expected project outcomes.

\section{Research Methodology}

The research was undertaken to investigate the duties performed by the management contractor and the required competencies for a management contractor. This will require a comprehensive and inductive study of management contracts.

In view of this, the study adopted the multi-case study research design involving the use of semi-structured interviews and documentary analysis of projects wherein management contracting was used. Since no published list that will enable identification of such contracts, purposeful snowballing sampling techniques was used, in which the determination and selection of cases was based on information received from experts and informants. This sampling technique identifies cases of interest from people who know people who know what contracts are information-rich; that is, right examples for the study and good interview subjects (Wengraf, 2001). Three recent cases of management contracts in South Africa were identified; semi-structured interviews with the key role player were carried out and permission was obtained to assess tender documents for documentary analysis in which relevant tender documents were evaluated and interpreted to obtain appropriate data for the study.

\section{Findings and Discussion}

The data collection involved an examination of project tender documents and semi-structured interviews with the key role players of the three case studies with over ten years' experience in construction at management level. The data generated from the semi-structured interview was analysed using content analysis facilitated with the use of Nvivo 11 qualitative analysis software to quickly identify prominent words, as well as key concepts across the three case studies. An analysis was made concerning prominent themes and issues arising from the cases studies. The project details of the three cases of management contracting identified in the study are extracted from tender documents and presented in Table 1. Table 1 shows the details of the project clients, implementing unit, description and location of the projects, and the selection strategy employed. Also, in Table 1 are the conditions of the contract, type of contractor required, performance bond required and the extent of subcontracting.

Table 1: Management Contracts Cases

\begin{tabular}{|c|c|c|c|}
\hline & $\begin{array}{l}\text { Case study } 1 \\
\text { (August 2013) }\end{array}$ & $\begin{array}{l}\text { Case study } 2 \\
\text { (August 2013) }\end{array}$ & $\begin{array}{l}\text { Case study } 3 \\
\text { (April 2014) }\end{array}$ \\
\hline $\begin{array}{l}\text { Description } \\
\text { and location } \\
\text { of project }\end{array}$ & $\begin{array}{l}\text { Refurbishment, extension or } \\
\text { alteration of existing } \\
\text { buildings for the development } \\
\text { of new Sol Plaatje University } \\
\text { in Kimberley, Northern Cape } \\
\text { Province }\end{array}$ & $\begin{array}{l}\text { Refurbishment, } \\
\text { extension or alteration of } \\
\text { existing buildings for the } \\
\text { development of the new } \\
\text { University of } \\
\text { Mpumalanga in } \\
\text { Nelspruit }\end{array}$ & $\begin{array}{l}\text { Refurbishment of educational and } \\
\text { healthcare facilities to improve } \\
\text { the quality of existing } \\
\text { infrastructure throughout the } \\
\text { Western Cape Province }\end{array}$ \\
\hline $\begin{array}{l}\text { Selection } \\
\text { strategy }\end{array}$ & $\begin{array}{l}\text { Framework contract, over a } \\
\text { three-year term without a } \\
\text { guarantee of a quantum of } \\
\text { work. }\end{array}$ & Same as "CS1." & $\begin{array}{l}\text { Framework contract/s over a } \\
\text { three-year term without a } \\
\text { commitment to a quantum of } \\
\text { work. }\end{array}$ \\
\hline $\begin{array}{l}\text { Conditions of } \\
\text { contract }\end{array}$ & $\begin{array}{l}\text { NEC3 ECC - Main Option F } \\
\text { (Management Contract). } \\
\text { Dispute resolution Option } \\
\text { W1: Dispute resolution and } \\
\text { secondary Options } \\
\text { X2 Changes in the law } \\
\text { X7: Delay Damages } \\
\text { X13: Performance Bond } \\
\text { Z: Additional conditions of } \\
\text { contract of the NEC3 } \\
\text { Engineering and Construction } \\
\text { Contract (June 2005) }\end{array}$ & Same as "CS1." & $\begin{array}{l}\text { NEC3 ECC - Main Option F } \\
\text { (Management Contract). } \\
\text { Dispute resolution Option W1: } \\
\text { and secondary Options } \\
\text { X2: Changes in the law } \\
\text { X5: Sectional completion } \\
\text { X7: Delay Damages } \\
\text { X13: Performance Bond } \\
\text { X20: Key performance indicators } \\
\text { Z: Additional conditions of } \\
\text { contract of the NEC3 Engineering } \\
\text { and Construction Contract (April } \\
\text { 2013) }\end{array}$ \\
\hline
\end{tabular}




\begin{tabular}{|c|c|c|c|}
\hline $\begin{array}{l}\text { Type of } \\
\text { contractor } \\
\text { required }\end{array}$ & $\begin{array}{l}\text { cidb contractor Grade } 6 \\
\text { CE or higher } \\
\text { Turnover }>\text { R } 18 \mathrm{~m} \\
\text { Previous refurbishment } \\
\text { projects }>\text { R7,0 million }\end{array}$ & $\begin{array}{l}\text { cidb contractor grade } \\
6 \mathrm{~GB} \text { or higher } \\
\text { Turnover }>\text { R } 15 \mathrm{~m} \\
\text { Previous refurbishment } \\
\text { projects }>\text { R7,5 million }\end{array}$ & - \\
\hline $\begin{array}{l}\text { Quality } \\
\text { evaluation of } \\
\text { contractor's } \\
\text { (tender) }\end{array}$ & $\begin{array}{l}\text { Experience of company, } \\
\text { experience of principal } \\
\text { management, i.e. the key } \\
\text { person responsible for } \\
\text { interfacing with the Project } \\
\text { Manager and the professional } \\
\text { team, Approach Paper } \\
\text { (Technical approach and } \\
\text { methodology) }\end{array}$ & Same as "Project 1." & $\begin{array}{l}\text { Experience of key person } \\
\text { responsible for interfacing with } \\
\text { the Project Manager, Approach } \\
\text { Paper (Technical approach and } \\
\text { methodology) }\end{array}$ \\
\hline Duration & 156 weeks after starting date & $\begin{array}{l}156 \text { weeks after starting } \\
\text { date }\end{array}$ & 3 years \\
\hline $\begin{array}{l}\text { Extent of } \\
\text { subcontracting }\end{array}$ & $\begin{array}{l}20.2 \text { Work which the } \\
\text { contractors will do is } \\
\text { confined to the establishment } \\
\text { and de-establishment of the } \\
\text { site and activities that may be } \\
\text { agreed with the Project } \\
\text { Manager from time to time. }\end{array}$ & $\begin{array}{l}20.2 \text { Work which the } \\
\text { contractors will do is } \\
\text { confined to the } \\
\text { establishment and de- } \\
\text { establishment of the site } \\
\text { and activities that may } \\
\text { be agreed with the } \\
\text { Project Manager from } \\
\text { time to time. }\end{array}$ & $\begin{array}{l}\text { Work which the Contractor will } \\
\text { do is confined to the } \\
\text { establishment and de- } \\
\text { establishment of the site, } \\
\text { maintenance, construction and } \\
\text { installation activities that may be } \\
\text { agreed with the Project Manager } \\
\text { from time to time. }\end{array}$ \\
\hline $\begin{array}{l}\text { Performance } \\
\text { bond }\end{array}$ & $7.5 \%$ & $7.5 \%$ & R 5,0 million \\
\hline
\end{tabular}

\subsection{Duties of Management Contractor}

From the documentary analysis of the project documents for the three case studies, the specific duties performed by the management contractor are presented in Table 2.

Table 2: Duties of Management Contractor

\begin{tabular}{|c|c|c|c|c|c|}
\hline Duties & Description & $\begin{array}{c}\text { Stage of } \\
\text { Project }\end{array}$ & $\begin{array}{l}\text { Case } \\
\text { study } 1\end{array}$ & $\begin{array}{l}\text { Case } \\
\text { study } 2\end{array}$ & $\begin{array}{l}\text { Case } \\
\text { study } 3\end{array}$ \\
\hline Management & $\begin{array}{l}\text { Manage the procurement process, the implementation of } \\
\text { project programmes, perform duties relating to overall } \\
\text { management of contract, site administration and provide } \\
\text { progress reports, }\end{array}$ & $\mathrm{P} \& \mathrm{C}$ & $\checkmark$ & $\checkmark$ & $\checkmark$ \\
\hline Co-ordinate & $\begin{array}{l}\text { Coordinate a considerable number of subcontractors, } \\
\text { service providers and material suppliers and supervises the } \\
\text { work of the subcontractors }\end{array}$ & $\mathrm{C}$ & $\checkmark$ & $\checkmark$ & $\checkmark$ \\
\hline Plan & $\begin{array}{l}\text { Planning at a package level including development of } \\
\text { maintenance plan and condition assessment and preparing } \\
\text { forecast to define cost of work at intervals }\end{array}$ & $\mathrm{P}$ & & & $\checkmark$ \\
\hline Direct & Direct the project team & $\mathrm{P} \& \mathrm{C}$ & $\sqrt{ }$ & $\checkmark$ & $\checkmark$ \\
\hline Design & Oversee development of design & $\mathrm{P}$ & & & $\checkmark$ \\
\hline Facilitate & Early start of work to meet deadlines & $\mathrm{P}$ & $\checkmark$ & $\checkmark$ & $\checkmark$ \\
\hline $\begin{array}{l}\text { Procure } \\
\text { Resources }\end{array}$ & $\begin{array}{l}\text { Procure resources that are necessary to provide the } \\
\text { required works and related professional design and } \\
\text { condition assessment services }\end{array}$ & $\mathrm{P} \& \mathrm{C}$ & & & $\checkmark$ \\
\hline $\begin{array}{l}\text { Execute } \\
\text { limited portion } \\
\text { of the work }\end{array}$ & $\begin{array}{l}\text { execute a limited part of the work with an own workforce, } \\
\text { site establishment and de-establishment and provision of } \\
\text { site facilities such as latrines, water and electrical services }\end{array}$ & $\mathrm{C}$ & $\checkmark$ & $\checkmark$ & $\checkmark$ \\
\hline $\begin{array}{l}\text { Contract } \\
\text { administration }\end{array}$ & $\begin{array}{l}\text { contracting, pricing and targeting strategy, and } \\
\text { procurement procedure for the portfolio of projects } \\
\text { administer package on behalf of the client, handover } \\
\text { completed works and close out of projects and packages }\end{array}$ & $\mathrm{P} \& \mathrm{C}$ & $\checkmark$ & $\checkmark$ & $\checkmark$ \\
\hline
\end{tabular}


Also, participants for semi-structured interviews for the study were selected based on their involvement in the management contracts under investigation. The interviews lasted for about an hour in each case. Participants were asked specific questions on the duties performed by the management contractor and the required competencies to perform these duties. Note taking, and audio recording of interviews was employed and was then transcribed and analysed using content analysis facilitated with the use of Nvivo 11 qualitative analysis software. The prominent themes from the participant's responses were brought together and are summarised as follows:

- The management contractor puts all service together like a turnkey development where all the team members report to the management contractor who integrates all team.

- The management contractor updates scope and concept to construction drawings and the preconstruction stage.

- The management contractor contributes to resolving design issues, reviewing drawings, constructability problems and issues on how to get the project delivered.

- Management contractors are active partners as part of the development and planning of design team and up to delivery

- The management contractor manages and control subcontractors and other occupations and big size labour force during the construction process

- Carry out induction, safety, and access arrangement

- Programming of works, getting people on time

- Ensuring site safety, managing the whole occupational safety, ensuring work is being secured on time in a safe and timely manner and safe working environment

- Provides training, induction and ensuring everyone has tools and equipment to work with

- Motivate people: keeping the construction team motivated

- Managing clients in controlling changes to scope as it affects cost and deadlines

\subsection{Required Competencies for management contractors to perform their duties}

- Sound knowledge of construction and building techniques and construction methodology such that will enable achieving the same outcome but in a better way and cheaper cost. If something is not working the management contractor should be able to come up with a solution.

- Construction methodology: knowledge of what is new in the market, what is best in the market, the ability to take a drawing and say something is missing or that does not tie in properly, or that there is a need for more information. Ability to interpret designs, schedule and manage workflows

- Leadership qualities

- Knowledge of construction business which is indicated by the number of years of experience in the business

- Analysing skills: management contractor should be able to examine projects and say this is the sequence of events, this is how to afford these things, and these are the different activities step and resources needed.

- Construction Management: Site administration, procuring subcontractors and then managing and coordinating their work quality and productivity. Being proactive solution driven on getting the job done as a team.

- Contract Management: Managing variety of contractual relationship with suppliers and subcontractors.

- Conflict Resolution: Ability to manage risk events when they occur and move forward.

- Relationship formation: providing a link and relationship among the professional team

- Financial management: the ability to manage cash flow by proper forward projecting so that projects do not run out of money.

\section{Discussion of findings}

The findings on the duties performed by a management contractor and the required competencies for a management contractor to perform these functions are discussed in this section.

\subsection{Duties performed by management contractors}

The tasks performed by management contractors were found to include duties carried out at both the preconstruction and construction stages of construction projects. This aligns with the submission of Murdoch and Hughes (2008). The main duties performed by management contractors discussed in this section include:

1. Construction management duties: The management contractor is responsible for the overall administration of the contract by putting and integrating all services together. The management contractor consults with and coordinates the professional team at the preconstruction stage and the work contractors at the construction stage. The management contractor also plans, organises, schedules and programmes design, work packages and site administration. Other construction management duties performed by a management contractor are supervision, monitoring and quality control, to ensure that work is being constructed correctly. Also, the management contractor carries out reporting and provision of required project information and facilitates early completion of projects. These duties aligned to management duties established by Henry Fayol in 1916 (Fayol, 1954) describes to include planning, organising, controlling, commanding, and coordinating.

2. Leadership duties: The management contractor plays an interpersonal role of head of the project team. Directs the project team and work contractors as well as keeps team members motivated while executing the project. Management contractors also act as the liaison; spoke person and resource allocator of the project.

3. Cost Control duties: here management contractors provide cost information to client and design team, prepares forecast to define the cost of work at intervals, carry out cost estimation of work packages, manages clients and the design team in controlling changes to scope 
as it affects cost and formulate the most cost-effective plan that will deliver the project within budget.

4. Buildability assessment duties: buildability assessment duties were adjudged as one of the core duties performed by the management contractor (Murdoch and Hughes, 2008; Sidwell, 1983). Management contractors are active partners of the design team and use their experience and expertise in construction to contribute to resolving design issues, reviewing drawings and designs alternatives, reviewing construction feasibility issues, assessing the availability of labour, materials, plants and equipment, and issues on how to get projects delivered. Also, the management contractor updates the scope and concept of the construction drawings, provides information on cost and materials, construction methodology, what is new and best in the market, and implications of various decisions in the course of the project.

5. Purchasing duties: Management contractor purchases and order materials, supplies and resources that is necessary to provide the required works.

6. Contracting duties: the management contractor is responsible for evaluating, selecting, negotiating, and going into contract relationship with subcontractors, suppliers, and other service providers in the client's interest. Also, management contractors are responsible for the establishment and de-establishment of the site at the completion of the project.

7. Conflict resolution duties: A management contractor manages disputes that may arise on site, and drafts and negotiates contracts properly to avoid ambiguities and dispute.

8. Relationship formation duties: Management contractors provide and facilitate links and relationship among project team as well as cooperate and seek cooperation with all persons involved in the project.

9. Health and Safety duties: here management contractors carry out duties ensuring site safety, manages the complete occupational safety, and ensuring work is being secured on time in a safe manner and in saving the working environment. Also, management contractors should ensure compliance with health and safety codes and regulations.

\subsection{Required Competencies to Perform as a} Management Contractor

Competency is the knowledge, skills, and behaviour necessary to perform well and keep up with the culture of an industry (Delo et al., 2010). Owing to the increased responsibilities assigned to the management contractor in a management contracting procurement system as indicated in the duties of a management contractor from the foregoing, the competencies required to perform as a management contractor differ from that needed to perform as a general contractor in a traditional

\section{References}

Alharthi, A., Soetanto, R. and Edum-Fotwe, F.T., 2014. Revisiting client roles and capabilities in construction procurement. In: Proceedings of the International Conference on Construction in a Changing World CIB W92 Procurement Systems, Sri Lanka, 2014, 12pp. procurement system of which financial and technical capabilities are key required competencies. The typical required competency for management contractors to carry out their functions identified in the study are: sound knowledge of construction techniques, good understanding of construction methodology, leadership skills including excellent temperament and self-control, knowledge of construction business, construction management skills (to include: programming, planning, organizing, coordinating, supervising and monitoring skills), analyzing skills, financial management skills, sound knowledge of contract management including knowledge of bid evaluation, negotiating power, relationship formation skills and conflict resolution skills. These competencies align with required competencies for management contractors and construction project managers as explained by Sidwell (1983) and Dainty et al. (2005).

\section{Conclusions}

This study aimed to investigate the duties performed by management contractors and the required competencies for a management contractor, to provide knowledge and understanding on important considerations for the selection of a management contractor. This will give a better understanding of the duties to be performed by a management contractor in a management contracting procurement system and the required competencies for one to perform as a management contractor. The research findings show that the duties performed by management contractors discussed in the study relate to construction management, leadership, cost control, buildability assessment, purchasing, contracting, conflict resolution, relationship formation, and health and safety duties. The identified required competencies to perform as a management contractor are sound knowledge of construction techniques, construction methodology, construction business, construction management, financial management, contract management, relationship formation and conflict resolution. Others are leadership and analysing skills.

The knowledge and understanding of the duties and required competencies to perform as management contractors provided in this study will help construction clients and the construction industry in the selection process, performance management and evaluation of management contractors. The findings from the study also give insight on the needed requirements for professional development and training for aspiring management contractors. Also, the findings from the study will have the potentials to provide documentation for reference in a future study on management contractor and selection of management contractors.

Chartered Institute of Building (CIOB) (2010) A report exploring procurement in the construction industry, Ascot: CIOB, Available at http://www.ciob.org/procurement (accessed 9.19.15).

Construction Industry Development Board, 2014. Construction Industry Indicators. Available at 
http://cidb.org.za/publications/Pages/ConstructionIndustry-Indicators.aspx (accessed 9.19.15).

Dainty, A.R., Cheng, M.-I., Moore, D.R., 2005. Competency-based model for predicting construction project managers' performance. J. Manag. Eng. 21, 2-9.

Delo, A., Hepworth, P., Hepworth, A., 2010. Assessing the competent project manager. Proj. Manag. Today 2-6.

Fayol, H., 2016. General and industrial management. Ravenio Books.

ISO 10845, 1, (2010). ISO 10845-1:2010 Construction procurement -- Part 1: Processes, methods and procedures. http://www.iso.org/iso/catalogue detail csnumber $=46190($ accessed 9.18.15) .

Meredith, J.R., Mantel Jr, S.J., 2011. Project management: a managerial approach. John Wiley \& Sons.

Mintzberg, H., 1973. The nature of managerial work. Harper Row.

Mirabile, R.J., 1997. Everything you wanted to know about competency modelling. Train. Dev. 51, 73-78.

Murdoch, J., Hughes, W., 2002. Construction contracts: law and management. Routledge.
Naoum, S.G., Langford, D., 1987. Management contracting - The client's view. J. Constr. Eng. Manag. 113, 369-384.

Naoum, S.G., 1994. Critical analysis of time and cost of management and traditional contracts. J. Constr. Eng. Manag. 120, 687-705.

RICS (2012) draft guidance note - Developing a building procurement strategy and selecting an appropriate procurement route, Available at https://consultations.rics.org/consult.ti/procurement/view CompoundDoc?docid=2704532 (accessed 9.10.15).

Sidwell, A., 1983. An evaluation of management contracting. Constr. Manag. Econ. 1, 47-55.

Smith, A.D., Offodile, O.F., 2008. Strategic importance of team integration issues in product development processes to improve manufacturability.Team Performance Management 14 (5/6), 269-292.

Ward, S.C., Curtis, B., Chapman, C.B., 1991. Advantages of management contracting-critical analysis. J. Constr. Eng. Manag. 117, 195-211.

Wengraf, T., 2001. Qualitative research interviewing: Biographic narrative and semi-structured methods. Sage. 